\title{
AN EXPERIMENTAL INVESTIGATION OF PHASE RELATIONS IN KIMBERLITE MELTS
}

\author{
RC Ogilvie-Harris, RA Brooker, MJ Walter and RSJ Sparks \\ School of Earth Sciences, University of Bristol, Wills Memorial Building, Bristol, BS8 1RJ
}

\section{INTRODUCTION}

The composition of kimberlite magma remains enigmatic partly due to the explosive eruption style, but also contamination by xenolithic material and strong alteration post-emplacement. Various kimberlite magma compositions have been hypothesized. Experiments at the conditions prior to and during emplacement provide an important way of testing the viability of such melts in reproducing the observed phase relations seen in the rocks. The results presented in this study extend the range of previous investigations (Sparks et al., 2009; Brooker et al., 2011) that have concluded the original 'magma' part of a kimberlite (i.e. xeno-lith/cryst free) may have a lower $\mathrm{SiO}_{2}$ and $\mathrm{MgO}$ content than the bulk rock composition measured for 'emplaced' rocks. This suggests the kimberlite melt are more 'transitional' towards a carbonatitic composition.

The composition of olivine in this series of experiments was surprising in terms of low $\mathrm{FeO}$ and high $\mathrm{CaO}$ contents. Such olivine-melt data may be useful in reconstructing the original coexisting melt composition from just the solid phase compositions in natural rocks. In particular we need to predict the partitioning of $\mathrm{MgO}$ and $\mathrm{FeO}$ between olivine and liquid $\left(\mathrm{K}_{\mathrm{D}(\mathrm{Fe}-\mathrm{Mg})}\right)$, as this mineral is a ubiquitous phase in a broad range of kimberlite rocks. It exerts a major control 'at source' where the magmas leave the upper mantle and controls the composition as magmas fractionate or accumulate this phase during their evolution on the way to the surface. The $\mathrm{CaO}$ content of olivine may also provide information on the melt and through equilibrium with coexisting monticellite the temperature of kimberlite magmas.

\section{METHODOLOGY}

Starting compositions used to test the viability of more 'transitional' compositions and $\mathrm{K}_{\mathrm{D}}$ values for olivine are based on very fresh natural kimberlitic rock compositions from Dutoitspan (Ogilvie-Harris et al., 2008), Wesselton and Jericho (Sparks et al. 2009; Brooker et al. 2011). The kimberlite rock compositions were systematically moved towards carbonatite as the original compositions were found to have very high and unrealistic liquidus temperatures. Examples of the resulting starting compositions are shown in Table 1.

The experiments were conducted at $100 \mathrm{MPa}$ and temperatures of $1100^{\circ} \mathrm{C}$ to $1250^{\circ} \mathrm{C}$ with mixed $\mathrm{CO}_{2}-\mathrm{H}_{2} \mathrm{O}$ volatile contents to simulate the conditions of kimberlitic melts during the eruption and emplacement of the hypabyssal intrusions at shallow levels in the crust.

\section{RESULTS}

\section{Melt compositions}

The first examined composition ROK1 (13.38 $\mathrm{wt} \% \mathrm{SiO}_{2}$ ) produced an abundant amount of apatite, spinel and approximately $58 \%$ melt at $1250^{\circ} \mathrm{C}$. ROK2 $\left(17.25 \mathrm{wt} \% \mathrm{SiO}_{2}\right)$ crystallised a 
more 'typical' kimberlite assemblage of olivine, monticellite, spinel, apatite but had minimal interstitial melt at $1250^{\circ} \mathrm{C}$, which was difficult to analyse.

Table 1. Compositions of the starting material

\begin{tabular}{ccccc}
\hline Oxides & $\begin{array}{c}\mathrm{ROK} 1 \\
\mathrm{Wt} \%\end{array}$ & $\begin{array}{c}\text { Vol } \\
\text { Free } \\
\text { basis }\end{array}$ & $\begin{array}{c}\text { ROK2 } \\
\mathrm{Wt} \%\end{array}$ & $\begin{array}{c}\text { Vol } \\
\text { Free } \\
\text { basis }\end{array}$ \\
\hline $\mathrm{SiO} 2$ & 13.38 & 15.67 & 17.25 & 20.57 \\
$\mathrm{TiO} 2$ & 5.26 & 6.15 & 4.14 & 4.93 \\
$\mathrm{~A} 2 \mathrm{O} 3$ & 4.88 & 5.72 & 3.85 & 4.59 \\
$\mathrm{Cr} 2 \mathrm{O} 3$ & 3.49 & 4.08 & 2.75 & 3.28 \\
$\mathrm{Fe} 2 \mathrm{O} 3$ & 2.25 & 2.64 & 2.11 & 2.52 \\
$\mathrm{FeO}$ & 6.91 & 8.09 & 6.48 & 7.73 \\
$\mathrm{MnO}$ & 0.17 & 0.20 & 0.16 & 0.19 \\
$\mathrm{MgO}$ & 10.18 & 11.93 & 16.09 & 19.19 \\
$\mathrm{NiO}$ & 0.12 & 0.14 & 0.11 & 0.13 \\
$\mathrm{CaO} *$ & 28.47 & 33.34 & 22.80 & 27.18 \\
$\mathrm{Na} 2 \mathrm{O}$ & 0.08 & 0.10 & 0.13 & 0.16 \\
$\mathrm{~K} 2 \mathrm{O}$ & 2.76 & 3.23 & 2.17 & 2.58 \\
$\mathrm{P} 2 \mathrm{O} 5$ & 5.87 & 6.87 & 4.61 & 5.49 \\
$\mathrm{BaO}$ & 0.57 & 0.66 & 0.44 & 0.53 \\
$\mathrm{SrO}$ & 1.01 & 1.19 & 0.80 & 0.95 \\
$\mathrm{Water}$ & 4.55 & - & 6.04 & - \\
$\mathrm{CO} 2$ & 10.05 & - & 10.08 & - \\
$\mathrm{Total}$ & 100.00 & 100.00 & 100.00 & 100.00
\end{tabular}

Unfortunately, the residual melts for both starting compositions (Figure 1) had characteristics that are likely inconsistent with 'residual' kimberlite matrix/melt, being very high in $\mathrm{CaO}$ and $\mathrm{SiO}_{2}$ with no evidence of calcite precipitation that is common in the groundmass of many natural kimberlites. To examine even more 'carbonatitic' compositions, a further carbonate component (50/50 mix of $\left.\mathrm{CaCO}_{3} / \mathrm{MgCO}_{3}\right)$ was added to ROK2 in varying proportions. Some of these very low $\mathrm{SiO}_{2}$ experiments did produce calcite that may be a stable phase or formed on the quench.

One of the problems with the results is that the temperatures needed to get reasonable amounts of melt are considerably higher than the estimates made for natural kimberlites.

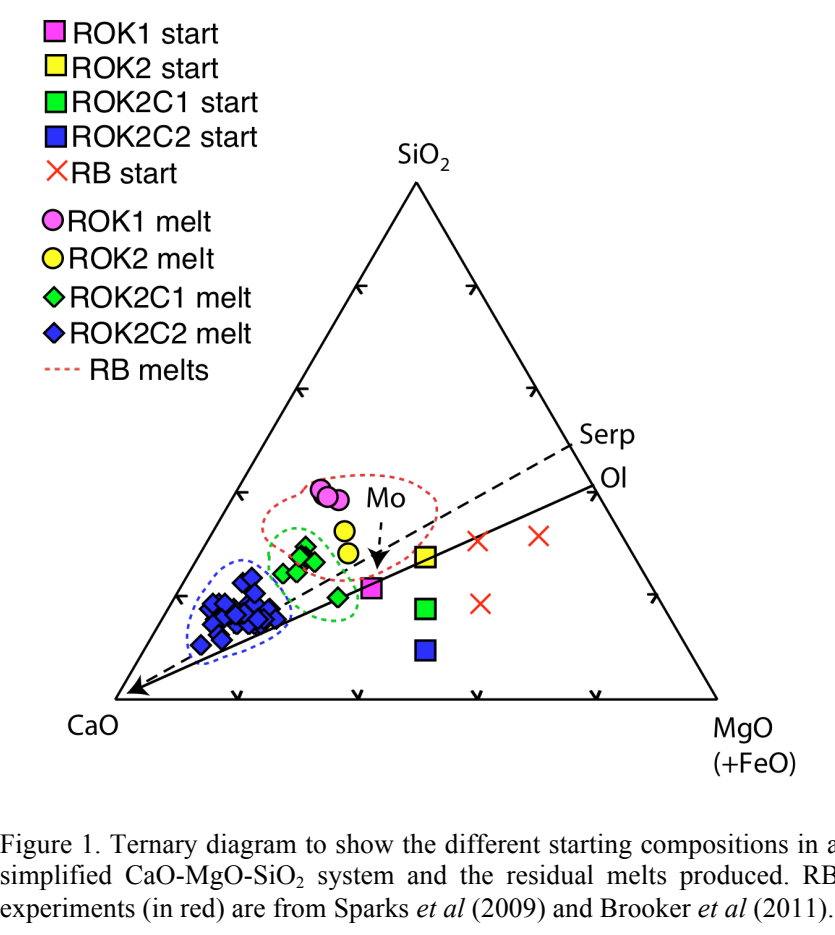

\section{OLIVINE COMPOSITIONS}

One of the surprising discoveries is the composition of olivines that have very high Fo contents giving a very low $\mathrm{K}_{\mathrm{D}(\mathrm{Fe}-\mathrm{Mg})}$ (see Figure 2).

\section{The $K_{D}$ Problem}

Roeder \& Emslie (1970) were the first to pair these elements in an exchange reaction between olivine and melt for use in correlating data in both experimental and natural systems. The olivineliquid exchange coefficient, known as $\mathrm{K}_{\mathrm{D}}$, is most correctly expressed as:

$$
\mathrm{K}_{\mathrm{D}}^{\mathrm{Fe}+\mathrm{Mg}}=(\mathrm{FeO} / \mathrm{MgO})_{\mathrm{Ol}} /(\mathrm{FeO} / \mathrm{MgO}) \text { melt }
$$

where $\mathrm{FeO}$ and $\mathrm{MgO}$ refer to concentrations (by weight). This is where the problems start as the melt can have any proportion of the $\mathrm{Fe}$ as either ferrous $\mathrm{Fe}^{2+}$ or ferric $\mathrm{Fe}^{3+}$ depending on the oxidation state of the system $\left(f \mathrm{O}_{2}\right)$, but also dependant on other compositional features of the melt. 
In contrast, the $\mathrm{Fe}$ in olivine is almost exclusively $\mathrm{Fe}^{2+}$. As a result it becomes critical to consider the $\mathrm{Fe}^{2+} / \mathrm{Fe}^{3+}$ ratio in the melt when calculating $\mathrm{K}_{\mathrm{D}}$. Based on early studies in the 70's it became an effective 'law' of igneous petrology that $K_{D}$ has a value of $0 \cdot 30 \pm 0 \cdot 03$, and that this was independent of temperature and liquid composition (Roeder and Emslie, 1970). In general, this value considered all $\mathrm{Fe}$ in the melt as $\mathrm{FeO}$. Eventually there was some consideration of the $\mathrm{Fe}^{2+} / \mathrm{Fe}^{3+}$ ratio in the melt, but analytical techniques did not allow a proper analysis of this ratio and it was generally back calculated to agree with a $K_{D}$ of 0.3 . Any olivine failing to meet this criterion is considered a 'xenocryst' out of equilibrium with its surroundings. For experimentalists in the laboratory, the failure to reproduce a value near 0.3 is considered a failure of the experiment (Beattie et al., 1991; Toplis, 2005) and an indication of disequilibrium. Unfortunately, the 0.3 paradigm has lead to a selfperpetuating myth with experiments falling outside the accepted range, filtered and eliminated from a data base that then continues to support the idea (Beattie et al., 1991). Some workers have shown that liquid composition does exert a 'significant' effect on $\mathrm{K}_{\mathrm{D}}$ (Gee and Sack, 1988; Kushiro and Walter, 1998; Toplis, 2005). However, these are minor effects compared with the variation found in this study (and Canil and Bellis, 2008).

\section{Experimental Olivines}

Figure 2 shows the olivine-melt $\mathrm{K}_{\mathrm{D}}$ calculated for the experiments (solid symbols) plotted against a compositional parameter mainly based on the $\mathrm{SiO}_{2}$ content and developed by Gee \& Sack (1988) to fit data for a range of igneous compositions. The experiments involved rather extreme, low-silica kimberlite compositions and the $\mathrm{K}_{\mathrm{D}}$ is plotted for an assumed $\mathrm{Fe}^{2+} / \mathrm{Fe}^{3+}$ values in the melt at NNO (based on the oxidation state most likely in the experiment) although values for a range of $f \mathrm{O}_{2}$ conditions are indicated. These in turn are calculated from the equation given by
Kress and Carmichael (1988) that shows the supposed ratio as a function of $f \mathrm{O}_{2}$ relative to a known buffer (NNO). For the experiment of this study the $\mathrm{Fe}^{2+} / \mathrm{Fe}^{\text {tot }}$ should be between $20 \%$ (NNO-2.5) and 60\% (NNO+2).

It is clear that the data do not give the traditional $K_{D}$ value of 0.3 and some petrologists would claim that equilibrium has not been achieved. However, the euhedral shape of the olivines and the lack of any zoning of $\mathrm{Fe}$ and $\mathrm{Mg}$ (or $\mathrm{Al}, \mathrm{Ca}$ or $\mathrm{P}$ ) suggest equilibrium has been achieved. In addition, an independent dataset from Canil and Bellis (2008) shows a similar range for $K_{D}$. An alternative possibility is that the melt composition has a much stronger

control and in particular, that there is significantly more $\mathrm{Fe}^{3+}$ in the melts than calculated from models such as Kress \& Carmichael, 1988. However, Ardnt et al., (2010) suggest that a much higher $K_{D}$ of 0.5 is more applicable olivines found in kimberlite.

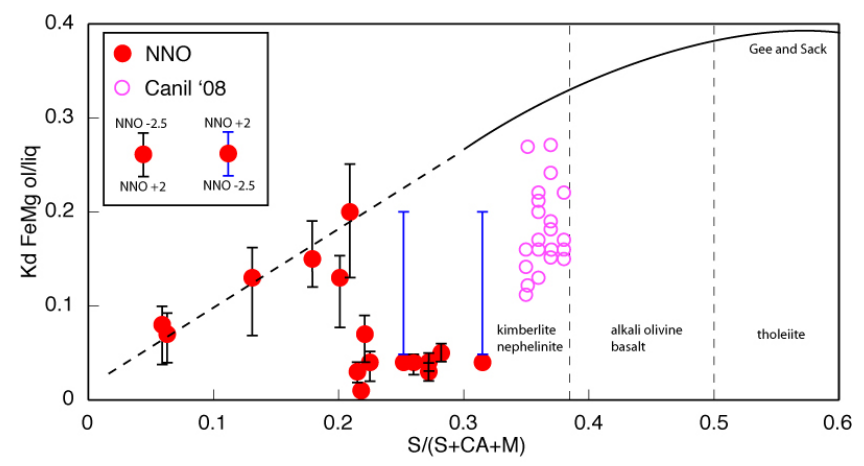

Figure 2. Olivine-liquid $\mathrm{K}_{\mathrm{D}}$ for kimberlite liquids in this study plotted against their degree of silica saturation given in terms of molar S, CA, and $\mathrm{M}$ components (where $\mathrm{S}=\mathrm{SiO}_{2}-4 \mathrm{Na}_{2} \mathrm{O}-4 \mathrm{~K}_{2} \mathrm{O} ; \mathrm{CA}=\mathrm{CaO}+\mathrm{Al}_{2} \mathrm{O}_{3}+3 \mathrm{Na}_{2} \mathrm{O}+$ $\mathrm{K}_{2} \mathrm{O}-0.33 \mathrm{P}_{2} \mathrm{O}_{5} ; \mathrm{M}=\mathrm{FeO}+\mathrm{MnO}+\mathrm{MgO}$, after Gee and Sack, (1988)). The $\mathrm{Fe}^{3+}$ contents for liquid compositions in equilibrium with olivine were calculated using the algorithm of Kress and Carmichael (1988). Canil '08 data is for a 'silica-rich' kimberlite from Canil \& Bellis, 2008).

Another feature of the experimental olivines is the high $\mathrm{CaO}$ content, which has a range from 0.38 to $3.98 \mathrm{wt} \%$, but is usually between 1.5 and $3 \mathrm{wt} \%$. We consider the systematics of $\mathrm{Ca}$ partitioning between the olivine and melt, but also the role of the olivine-monticellite solvus. This may give complementary data on the temperature 


\section{$10^{\text {th }}$ International Kimberlite Conference, Bangalore - 2012}

of equilibration as shown in Figure 3. The lower $\mathrm{CaO}$ content observed in natural kimberlites $(<$ $1.0 \mathrm{wt} \%$ ), indicating much lower equilibration temperature than our experiments.

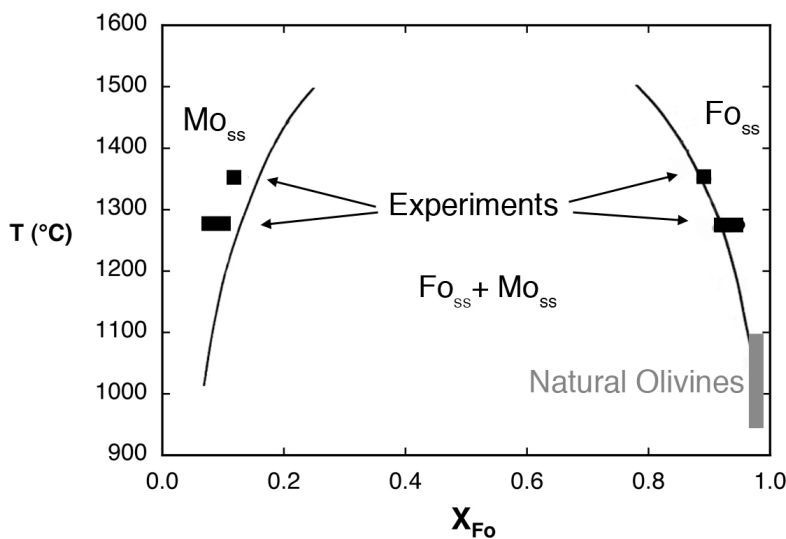

Figure 3. Olivine-monticellite solves as a function of temperature (from Adams and Bishop, 1985). Experiments at 1275 and $1350^{\circ} \mathrm{C}$ have compositions close to the solvus. Natural olivine phenocrysts suggest lower temperatures.

As well as providing information on the melt composition and temperature, the understanding of olivine compositions will help to unravel the confusion that results from a variety of olivine populations (xenoliths, xenocrysts, macrocrysts, phenocrysts and groundmass) that may have reequilibrated (or not) during the evolution and ascent of the kimberlite magma.

\section{REFERENCES}

Adams, G.E \& Bishop, F.C. (1985). An experimental investigation of thermodynamic mixing properties and unit-cell parameters of forsterite-monticellite solid solution. American Mineralogist 70, 714-722

Ardnt, N.T., Guitreau, A.-M, Boullier, A., Le Roex, A., Tommasi, A., Cordier, P. and Sobolev, A. (2010). Olivine and the Origin of Kimberlite. Journal of Petrology 51, 573-602

Beattie, P., Ford, C. and Russell, D. (1991). Partition coefficients for olivine-melt and orthopyroxene-melt systems. Contributions to Mineralogy and Petrology 109, 212-224

Brooker R.A., Sparks R.S.J, Kavanagh J. and Field M. (2011) The volatile content of hypabyssal kimberlite magmas: Some constraints from experiments on natural rock compositions. Bulletin of Volcanology 73, 959-981.

Canil, D. and Bellis, A.J. (2008) Phase equilibria in a volatile-free kimberlite at $0.1 \mathrm{MPa}$ and the search for a primary kimberlite magma. Lithos 105, 111-117
Gee, L. L. and Sack, R. O. (1988). Experimental petrology of melilite nephelinite. Journal of Petrology 29, 1233-1255.

Hart, S. R. and Davis, K. E. (1978). Nickel partitioning between olivine and silicate melt, Earth and Planetary Science Letter 40, 203-219

Kress, V. C. and Carmichael, I. S. E. (1988). Stoichiometry of the iron oxidation reaction in silicate melts. American Mineralogist 73, 1267-1274

Kushiro I. and Walter M. J. (1998) Mg-Fe partitioning between olivine and mafic-ultramafic melts. Geophysical Research Letters, 25, 2337-2340

Ogilvie-Harris, R.C., Sparks, R.S.J., Walter, M., Field, M. (2008). Melt compositions and eruptive conditions inferred from the petrology of Dutoitspan kimberlite. Extended abstracts, 9th International Kimberlite Conference, Frankfurt, Germany

Roeder, P. L. and Emslie, R. F. (1970). Olivine-liquid equilibrium. Contributions to Mineralogy and Petrology 29, 275-289

Sparks, R. S. J., Brooker R.A., Field, F., Kavanagh, J., Schumacher, J. C., Walter, M. J. and White, J. (2009). Lithos 112S, 429-438.

Toplis, M. J. (2005). The thermodynamics of iron and magnesium partitioning between olivine and liquid: criteria for assessing and predicting equilibrium in natural and experimental systems. Contributions to Mineralogy and Petrology 149, 2239 